\title{
Peran Dan Kebijakan Pemerintah Terhadap Peningkatan Koperasi Nelayan Kota Tanjungpinang
}

\author{
Lia Suprihartin, Roni Kurniawan \\ Fakultas Ekonomi Universitas Maritim Raja Ali Haji, Tanjungpinang, Kepulauan Riau, Indonesia
}

\begin{abstract}
ABSTRAK : Objek penelitian mengenai pengaruh peran dan kebijakan pemerintahterhadap peningkatan koperasi nelayan kota tanjungpinang. Tipe dari penelitian adalah deskriptif kuantitatif. Hasil hasil dari penelitian menunjukkan bahwa Peran Pemerintah $\left(\mathrm{X}_{1}\right)$ berpengaruh secara parsial terhadap Peningkatan Koperasi (Y) dengan nilai uji -t sebesar 3,090 dan nilai signifikansi adalah 0,005. Variabel Kebijakan Pemerintah (X2) tidak berpengaruh secara parsial terhadap Peningkatan Koperasi (Y) dengan nilai uji-t sebesar -1,006 dan nilai signifikansi adalah 0,323 di atas dari 0,05. Pada Uji simultan (Uji-F) Peran (X1) dan Kebijakan Pemerintah (X2) berpengaruh secara simultan terhadap Peningkatan Koperasi (Y) dengan nilai yaitu 63,701 dan nilai signifikansi adalah 0,000 di bawah dari 0,05
\end{abstract}

Keywords: Peran Pemerintah, Kebijakan Pemerintah, Koperasi Nelayan

Email Address : liasuprihartini@umrah.ac.id/ronik@umrah.ac.id 


\section{PENDAHULUAN}

Koperasi yang tumbuh dan berkembang seiring dengan kemajuan kinerja yang semakin baik tidak terlepas dari sikap dan kebijakan pemerintah yang menggambarkan sikap yang berbeda dengan tindakan Negara lainnya. Pertumbuhan gerakan koperasi ditentukan oleh sikap yang diperlihatkan pemerintah terhadap koperasi.Kelompok nelayan dari komunitas desa pesisir, pada umumnya adalah bagian dari kelompok masyarakat miskin yang berada pada level paling bawah dan acapkali menjadi korban pertama yang paling menderita akibat ketidakberdayaan dan kerentanannya.Ekonomi rakyat pada umumnya usaha mikro yang merupakan sektor ekonomi yang digeluti oleh rakyat kebanyakan, seperti para anggota Koperasi Perikanan di Kota Tanjungpinang menjadikan koperasinya sebagai usaha mikro. Mengingat pentingnya sektor usaha mikro yang telah tergabung dalam koperasi, maka gerakan koperasi harus menjadi prioritas pembinaan dan pengembangan usahanya, karena usaha demikian dapat menyediakan lapangan pekerjaan, dan mengurangi pengangguran. Maka sudah sewajarnya kalau sektor mikro yang tergabung dalam koperasi mendapatkan perhatian untuk lebih dikembangkan sehingga benar-benar dapat menjadi penyangga utama perekonomian nasional. Adapun daftar Koperasi nelayan di Kota Tanjungpinang adalah pada Tabel 1.1 di bawah ini.

Tabel 1.1

Daftar Koperasi Nelayan Tangkap

Kota Tanjungpinang

\begin{tabular}{|c|l|l|c|}
\hline No & \multicolumn{1}{|c|}{$\begin{array}{c}\text { Nama } \\
\text { Koperasi }\end{array}$} & \multicolumn{1}{|c|}{ Alamat } & $\begin{array}{c}\text { Jenis } \\
\text { Usaha }\end{array}$ \\
\hline 1 & $\begin{array}{l}\text { Koperasi } \\
\text { Tanjung } \\
\text { Siambang } \\
\text { Dompak }\end{array}$ & $\begin{array}{l}\text { Tanjung } \\
\text { Siambang } \\
\text { RT.002/RW.001 }\end{array}$ & $\begin{array}{c}\text { Perikanan } \\
\text { Tangkap }\end{array}$ \\
\hline 2 & Koperasi & Kampung Bugis & Perikanan \\
\hline
\end{tabular}

\begin{tabular}{|c|c|c|c|}
\hline & $\begin{array}{l}\text { Serba } \\
\text { Usaha } \\
\text { (KSU) } \\
\text { Berkat } \\
\text { Bersama }\end{array}$ & RT.001/RW.006 & Tangkap \\
\hline 3 & $\begin{array}{l}\text { Koperasi } \\
\text { Nelayan } \\
\text { Teluk } \\
\text { Keriting } \\
\text { Jaya }\end{array}$ & $\begin{array}{l}\text { Jl.Usman Harun } \\
\text { RT.004/RW.015 }\end{array}$ & $\begin{array}{c}\text { Perikanan } \\
\text { Tangkap }\end{array}$ \\
\hline 4 & $\begin{array}{l}\text { KSU } \\
\text { Menur } \\
\text { Juang } \\
\text { Jaya }\end{array}$ & $\begin{array}{l}\text { RT/RW 04/09 } \\
\text { Kel. Sei Jang }\end{array}$ & $\begin{array}{l}\text { Perikanan } \\
\text { Tangkap }\end{array}$ \\
\hline 5 & $\begin{array}{l}\text { Koperasi } \\
\text { Serba } \\
\text { Usaha } \\
\text { (KSU) } \\
\text { Perikanan } \\
\text { Usaha }\end{array}$ & $\begin{array}{l}\text { Madung } \\
\text { RT.001/RW.005 }\end{array}$ & $\begin{array}{l}\text { Perikanan } \\
\text { Tangkap }\end{array}$ \\
\hline 6 & $\begin{array}{l}\text { Koperasi } \\
\text { Serba } \\
\text { Usaha } \\
\text { (KSU) } \\
\text { Budi } \\
\text { Mulia }\end{array}$ & $\begin{array}{l}\text { Madung } \\
\text { RT.001/RW.005 }\end{array}$ & $\begin{array}{c}\text { Perikanan } \\
\text { Tangkap }\end{array}$ \\
\hline
\end{tabular}

\section{PERUMUSAN MASALAH}

1. Apakah peran pemerintah berpengaruh terhadap peningkatkan koperasi nelayan kota tanjungpinang?

2. Apakah kebijakan pemerintah berpengaruh terhadap peningkatkan koperasi nelayan kota tanjungpinang?

3. Apakah peran dan kebijakan pemerintah berpengaruh terhadap peningkatkan koperasi nelayan kota tanjungpinang?

\section{Tujuan Penelitian}

1. Untuk meneliti dan menganalisis pengaruh signifikan peran pemerintah berpengaruh 
terhadap peningkatkan koperasi nelayan kota tanjungpinang

2. Untuk meneliti dan menganalisis pengaruh signifikan kebijakan pemerintah berpengaruh terhadap peningkatkan koperasi nelayan kota tanjungpinang

3. Untuk meneliti dan menganalisis pengaruh signifikan peran dan kebijakan pemerintah berpengaruh terhadap peningkatkan koperasi nelayan kota tanjungpinang

\section{KAJIAN PUSTAKA}

\section{Pengertian Koperasi}

Koperasi merupakan badan usaha bersama yang bertumpu pada prinsip ekonomi kerakyatan yang berdasarkan atas asas kekeluargaan. Berbagai kelebihan yang dimiliki oleh koperasi seperti efisiensi biaya serta dari peningkatan economies of scale jelas menjadikan koperasi sebagai sebuah bentuk badan usaha yang sangat prospekrif di Indonesia. Namun, dari kelebihan tersebut justru koperasi masih sangat sulit untuk berkembang di Indonesia. Dalam perkembangannya koperasi masih saja mengalami pasang surut meskipun upaya Pemerintah untuk memberdayakan koperasi seolah tidak pernah habis. Berbagai bantuan dari Pemerintah seperti KKop, Kredit Usaha Tani (KUT), pengalihan saham (satu persen) dari perusahaan besar ke Koperasi, skim program KUK dari bank dan Kredit Kesehatan Pangan yang merupakan kredit komersial dari perbankan, Permodalan Nasional Madani (PNM), terus mengalir untuk memberdayakan gerakan ekonomi kerakyatan ini. Tak hanya bantuan program, ada institusi khusus yang menangani di luar Dekopin, yaitu Menteri Negara Urusan Koperasi dan PKM (Pengusaha Kecil Menengah), yang sebagai memacu gerakan ini untuk terus maju. Namun, kenyataannya, Koperasi masih saja melekat dengan stigma ekonomi marjinal, pelaku bisnis yang perlu "dikasihani". Adapun berbagai permasalahan yang sering dihadapi di Koperasi
1. Kurangnya partisipasi anggota

2. Sosialisasi Koperasi

3. Manajemen

4. Permodalan

5. Sumber daya manusia

6. Kurangnya keadaan masyarakat

7. Demokrasi ekonomi yang kurang

\section{Peran dan Kebijakan Pemerintah Kepada Koperasi}

Adapun peran dan kebijakan Pemerintah terhadap Koperasi :

1. Antagonism (antipati)

Pada mulanya timbul gerakan Koperasi di negara-negara, pemerintah pada waktu itu memperlihatkan sikap merintangi atau melakukan pengawasan yang keras terhadap koperasi. Sikap-sikap tersebut ditunjukkan dengan sistem perpajakan yang tidak adil, peraturan-peraturan atau undang- undang yang mencegah atau menyulitkan dalam hal menjalankan teknik ke- koperasian. Di negaranegara totaliter terlihat pengawasan Pemerintah yang berlebihan terhadap gerakan Koperasi. Pemerintah memberikan aturan yang sangat sulit untuk dipenuhi oleh rakyat dengan bayaran pajak yang tinggi ataupun birokrasi administrasi yang berbelit-belit. Hal ini pernah terjadi di Indonesia pada masa penjajahan Belanda. Pemerintahan Belanda berupaya menghalangi pembentukan koperasi karena khawatir akan menjadi kekuatan yang dapat melawan pemerintahan Belanda.

2. Indiference (Netral)

Sikap pemerintah yang memperlakukan koperasi sama dengan berbagai bentuk badan usaha lain. Sikap acuh tak acuh atau tidak memperhatikan ternyata dari tidak adanya peraturan-peraturan yang memungkinkan koperasi bekerja secara wajar. Sikap pemerintah tersebut sepertinya tidak menggambarkan sikap menghalangi gerakan, tetapi tidak pula mengerti bahwa gerakan koperasi itu merupakan bagian yang dinamis dalam perekonomian serta sosial negara-negara dan negara berlaku seolah-olah gerakan ini tidak ada. Sikap ini sering muncul 
di negara-negara Eropa dimana koperasi baru lahir.

Sikap pemerintah yang acuh tak acuh (indifference), biasanya terjadi pada saat koperasi baru berdiri pada negara atau daerah yang menganut otonomi daerah. Pemerintahannya tidak memberikan perhatian ataupun layanan yang memadai terhadap koperasi. Sehingga koperasi yang ada seakanakan ada dan tiada.

\section{Over Sympaty (terlalu simpati)}

Sikap pemerintah yang memanjakan atau membantu berlebihan terhadap koperasi. Ada beberapa negara yang memberikan perhatian sangat besar terhadap gerakan koperasi. Pemerintah ingin sekali menjalankan segala sesuatu sedapat- dapatnya bahkan memberikan bantuan yang berlebih-lebihan untuk gerakan koperasi. Semua itu dilakukan karena sistem koperasi dianggap sebagai organisasi rakyat yang baik dan tepat untuk mengadakan perbaikan ekonomi dan sosial masyarakat di negara-negara bersangkutan. Wujud sikap over sympaty ini ialah memberikan dorongan secara aktif untuk pembentukan koperasi-koperasi secara cepat. Namun hal ini justru merugikan koperasi itu sendiri karena kelangsungan hidupnya tergantung oleh bantuan pemerintah. Dalam perkembangan perkoperasian ini, Indonesia pernah mendapatkan sikap tersebut yaitu pada saat koperasi terlahir. Berdirinya koperasi mendapatkan dorongan dari Pemerintah yaitu dengan memberikan bantuan tenaga atau modal.

\section{Wheel Balance (Simpati)}

Sikap ideal (well balanced), pemerintah memberikan bantuan yang wajar sesuai dalam batas dan prinsip koperasi. Pemerintah tidak memanjakan koperasi, sehingga koperasi dapat berkembang dengan baik dan mampu mandiri pada akhirnya. Koperasi yang tumbuh dan berkembang seiring dengan kemajuan kinerja yang semakin baik tidak terlepas dari sikap dan kebijakan pemerintah yang menggambarkan sikap yang berbeda dengan tindakan negara lainnya. Pertumbuhan gerakan koperasi ditentukan oleh sikap yang diperlihatkan pemerintah terhadap koperasi. Sikap-sikap pemerintah terhadap setiap koperasi berbedabeda sesuai dengan kondisi koperasi tersebut. Sikap pemerintah dapat bersifat berlawanan, acuh tak acuh, simpati berlebihan dan seimbang. Sikap ini tergantung dari kondisi koperasi. Pada umumnya sikap pemerintah terhadap koperasi yang diterapkan di Indonesia adalah sikap over sympathy dan well balance . Kedua sikap tersebutlah yang mendasari perkembangan dan pasang surut koperasi sampai saat ini. Pada dasarnya pemerintah, berupaya untuk menumbuh kembangkan koperasi menjadi alternatif gerakan kekuatan ekonomi rakyat. Oleh karena itu, perlu dipelajari dan dipahami sikap dan kebijakan pemerintah mana yang paling cocok untuk diterapkan pada Koperasi Indonesia untuk menghadapi gempuran globalisasi.

Dari empat sikap dan kebijakan Pemerintah tersebut, menurut pendapat peneliti sikap pemerintah yang antipati terhadap koperasi pernah terjadi di negara Jerman pada masa pemerintahan Hilter. Sikap antipasti tersebut juga pernah terjadi di Hindia Belanda (Indonesia) pada zaman penjajahan karena pada masa itu pemerintah jajahan merasakan bahaya dengan adanya koperasi sebagai organisasi rakyat yang mengajarkan demokrasi. Sikap pemerintah yang netral terhadap koperasi terdapat antara lain di negara Amerika Serikat dan Australia dimana koperasi harus bersaing dengan badan usaha lain, siapa yang kuat maka akan menang.

Sikap terlalu simpati pada koperasi tercermin pada peranan pemerintah yang memasuki manajemen koperasi untuk membantu koperasi. Namun, sikap tersebut dapat mematikan inisiatif yang tumbuh dari koperasi sendiri karena membuat koperasi menjadi tidak mandiri. Sikap simpati pada koperasi ditunjukkan oleh berbagai negara seperti India, Malaysia, Korea, dan Indonesia dimana pemerintah memberikan iklim yang baik kepada koperasi untuk melakukan usahanya. Peran pemerintah disini bukan untuk 
memasuki manajemen koperasi, melainkan untuk memberikan dorongan kepada koperasi untuk memajukan koperasi karena hal tersebut pemerintah tidak ikut campur dalam pengambilan keputusan, tetapi koperasi sendirilah yang mengambil keputusannya. Pemerintah di negara-negara sedang berkembang pada umumnya turut aktif dalam upaya membangun koperasi dengan tujuan untuk mendorong adanya kesadaran untuk menggerakan koperasi yang dapat mensejahterakan masyarakat. Keikutsertaan pemerintah dalam pembinaan koperasi tersebut dapat berlangsung secara efektif, tentu perlu dilakukan koordinasi antara satu bidang dengan bidang lainnya. Tujuannya adalah agar terdapat keselarasan dalam menentukan pola pembinaan koperasi secara nasional. Terbangunnya keselarasan dalam pola pembinaan maka diharapkan dapat benar-benar meningkatnya kemampuannya, baik dalam meningkatkan kesejahteraan anggota dan masyarakat disekitarnya, maupun dalam turut serta membangun system perekonomian nasional.

Peranan pemerintah dalam gerakan koperasi antara lain dengan:

1. Memberi bimbingan berupa penyuluhan, pendidikan ataupun melakukan penelitian bagi perkembangan koperasi serta bantuan konsultasi terhadap permasalahan koperasi

2. Melakukan pengawasan termasuk memberi perlindungan terhadap koperasi berupa penetapan bidang kegiatan ekonomi yang telah berhasil diusahakan oleh koperasi untuk tidak diusahakan oleh badan usaha lainnya

3. Memberikan fasilitas berupa kemudahan permodalan, serta pengembangan jaringan usaha dan kerja sama.

Pemerintah untuk menjalankan tiga peran/tugas utamanya tersebut yakni:

1. Peran untuk memelihara keamanan dalam negeri dan pertahanan.

2. Peran untuk menyelenggarakan peradilan yang seadil-adilnya.
3. Peran untuk menyediakan barang-barang yang tidak disediakan sektor swasta.

Menurut Dumairy (1996) peranan pemerintah dapat dibedakan menjadi empat kelompok yaitu :

1. Peran alokatif, yaitu peranan pemerintah dalam mengalokasikan sumber daya ekonomi yang ada agar pemanfaatannya bisa optimal dan mendukung efisiensi produksi.

2. Peran distributif, yaitu peranan pemerintah dalam mendistribusikan sumber daya, kesempatan dan hasil-hasil ekonomi secara adil dan wajar.

3. Peran stabilisasi, yaitu peranan pemerintah dalam memelihara stabilitas perekonomian dan memulihkannya jika berada dalam keadaan disequilibrium.

4. Peran dinamisatif, yaitu peranan pemerintah dalam menggerakkan proses pembangunan ekonomi agar lebih cepat tumbuh, berkembang, dan maju

Peran pemerintah ini penting agar keberadaan koperasi terus berkembang maju dan meningkatkan taraf hidup masyarakat, terutama rakyat miskin. Dalam masalah ini, pemerintah membuat program yang disebut KUR (Kredit Usaha Rakyat). Kredit Usaha Rakyat, yang selanjutnya disingkat KUR, adalah kredit/ pembiayaan kepada Usaha Mikro Kecil Menengah Koperasi (UMKM-K) dalam bentuk pemberian modal kerja dan investasi yang didukung fasilitas penjaminan untuk usaha produktif.

\section{KERANGKA KONSEPTUAL}

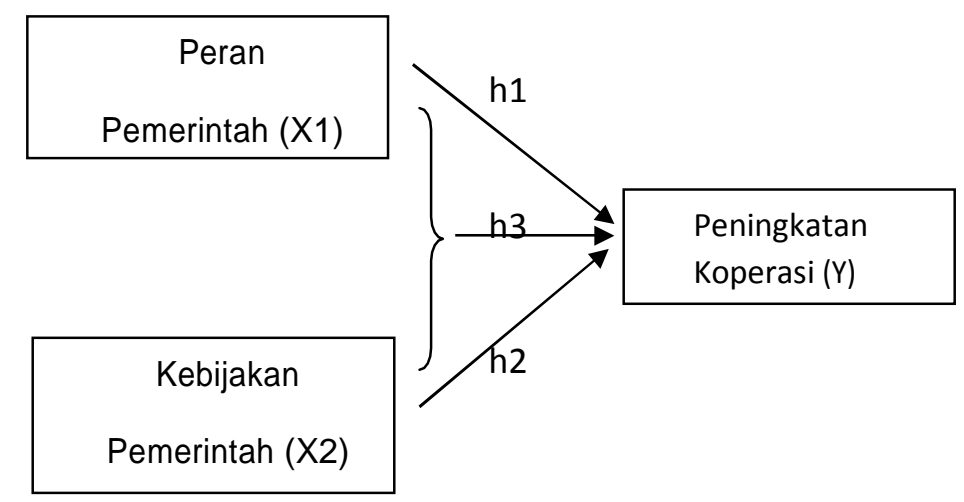




\section{HIPOTESIS}

Dari kerangka pemikiran yang digambarkan diatas, maka hipotesis penelitian ini adalah sebagai berikut :

H1 : Peran pemerintah berpengaruh terhadap peningkatkan koperasi nelayan kota tanjungpinang

H2 : Kebijakan pemerintah berpengaruh terhadap peningkatkan koperasinelayan kotatanjungpinang

H3 : Peran dan kebijakan pemerintah berpengaruh terhadap peningkatkan

koperasi nelayan kotatanjungpinang

\section{METODE PENELITIAN}

Jenis penelitian pada penelitian ini adalah penelitian kuantitatif. Menurut Sugiyono (2015 :35) kuantitatif adalah metode penelitian yang berlandasan pada filsasaf positivisme yang digunakan untuk meneliti populasi atau sampel tertentu, pengumpulan data dengan menggunakan instrumen penelitian, analisis data bersifat kuantitatif/statistik, dengan tujuan untuk menguji hipotesis yang telah ditetapkan. Berdasarkan pendapat tersebut dapat dipahami pengaruh yang ingin diketahui dalam penelitian ini yaitu Peran Pemerintah (X1), Kebijakan Pemerintah (X2), serta Peningkatan Koperasi (Y).

\section{Tempat dan PopulasiPenelitian}

Tempat penelitian ini dilakukan di Koperasi Nelayan Kota Tanjungpinang Provinsi Kepulauan Riau sedangkan populasi menurut Sugiono (2015 : 80) populasi adalah wilayah generalisasi yang terdiri atas objek atau subjek yang mempunyai kualitas dan karakteristik tertentu yang ditetapkan oleh peneliti untuk dipelajari dan kemudian ditarik kesimpulannya. Maka dari itu populasi penelitiannya adalah Koperasi nelayan terdiri dari 6 (Enam) Koperasi di Kota Tanjungpinang.

\section{Sampel dan DataPenelitian}

Pengambilan sampel yang digunakan dalam penelitian ini adalah teknik nonprobability sampling Nonprobability Sampling dengan teknik Purposive Sampling adalah teknik pengambilan sampel yang tidak memberi peluang atau kesempatan sama bagi setiap unsur atau anggota populasi untuk dipilih menjadi sampel dengan pertimbangan tertentu. Dalam penelitian ini maka peneliti akan mengambil sampel kepada para pemimpin koperasi terdiri dari ketua, wakil ketua, bendahara, sekretaris dan 1 (satu) orang anggota koperasi nelayan sehingga jika ditotal sebanyak $5 \times$ x 6 Koperasi Nelayan $=30$ responden

\section{Teknik Pengumpulan Data}

Adapun teknik pengumpulan data yang digunakan dalam penelitian ini adalah :

1. Kuesioner

Kuesioner merupakan teknik pengumpulan data yang dilakukan dengan cara memeberikan seperangkat pertanyaan atau pernyataan tertulis kepada para responden untuk dijawab.

2. Observasi

Observasi merupakan pengamatan dan pencatatan secara sistematik terhadap gejala yang tampak pada objek penelitian.

3. Studi Pustaka

Studi kepustakaan yaitu mengadakan penelitian dengan cara mempelajari dan membaca literatur-literatur, jurnal-jurnal, dan referensi yang ada hubungannya dengan permasalahan yang menjadi objek penelitian.

\section{Metode Analisis Data}

1. Pengeditan (Editing)

Pengeditan adalah sebuah proses pemilihan atau pengambilan data-data yang diperlukan dan membuang data yang tidak perlu. Hal ini dilakukan untuk memudahkan perhitungan didalam pengajuan hipotesis.

2. Pemberian Skor (scoring)

Di dalam penelitian ini, proses scoring menggunakan skala likert. Skala likert digunakan untuk mengukur sikap dan 
pendapat karyawan tentang variabel yang diteliti. Subjek mendapatkan nilai dari sikap pernyataan sesuai dengan nilai skala kategori jawaban yang diberikan. Skala yang digunakan didalam penelitian ini menggunakan skala liker 1-5 yaitu :

1) Sangat Tidak Setuju (TS): skor 1

2) Tidak Setuju (TS) : skor 2

3) Setuju (S) : skor 3

4) Sangat Setuju (SS) : skor 4

\section{HASIL PENELITIAN DAN PEMBAHASAN}

\section{PENGARUH PERAN PEMERINTAH TERHADAP PENINGKATAN KOPERASI}

\section{(a) Pengujian Hipotesis Pertama}

Berdasarkan hasil perhitungan dalam uji parsial (Uji-t) maka diperoleh besarnya pengaruh langsung dari Peran Pemerintah $\left(\mathrm{X}_{1}\right)$ terhadap Peningkatan Koperasi (Y) yaitu 3,090 dan nilai signifikansi adalah 0,005

Interprestasi hipotesis penelitian pada hipotesis pertama menyatakan Peran Pemerintah $\left(\mathrm{X}_{1}\right)$ berpengaruh secara parsial terhadap Peningkatan Koperasi (Y).Dalam hal ini hipotesis penelitian teruji artinya variabel Peran Pemerintah $\left(\mathrm{X}_{1}\right)$ berpengaruh secara parsial terhadap Peningkatan Koperasi (Y).

\section{(b)Pengujian Hipotesis Kedua}

Berdasarkan hasil perhitungan dalam uji parsial (Uji-t) maka diperoleh besarnya pengaruh langsung dari Kebijakan Pemerintah $\left(\mathrm{X}_{2}\right)$ terhadap Peningkatan Koperasi (Y) yaitu -1,006 dan nilai signifikansi adalah 0,323 di atas dari 0,05

Interprestasi hipotesis penelitian pada hipotesis kedua menyatakan Kebijakan Pemerintah $\left(\mathrm{X}_{2}\right)$ tidak berpengaruh secara parsial terhadap Peningkatan Koperasi (Y).Dalam hal ini hipotesis penelitian tidak teruji artinya variabel Kebijakan Pemerintah $\left(X_{2}\right)$ tidak berpengaruh secara parsial terhadap Peningkatan Koperasi (Y).

\section{(c)Pengujian Hipotesis Ketiga}

Berdasarkan hasil perhitungan dalam uji simultan (Uji-F) maka diperoleh besarnya pengaruh simultan dari Peran $\left(\mathrm{X}_{1}\right)$ dan Kebijakan Pemerintah $\left(\mathrm{X}_{2}\right)$ terhadap Peningkatan Koperasi (Y) yaitu 63,701 dan nilai signifikansi adalah 0,000 di bawah dari 0,05

Interprestasi hipotesis penelitian pada hipotesis Ketiga menyatakan Peran $\left(\mathbf{X}_{1}\right)$ dan Kebijakan Pemerintah $\left(\mathrm{X}_{2}\right)$ berpengaruh secara simultan terhadap Peningkatan Koperasi (Y). Dalam hal ini hipotesis penelitian teruji artinya variabel Peran $\left(\mathbf{X}_{1}\right)$ dan Kebijakan Pemerintah $\left(\mathbf{X}_{2}\right)$ berpengaruh secara simultan terhadap Peningkatan Koperasi (Y).

\section{KESIMPULAN}

Berdasarkan dari data deskriptif,hasil analisis data dan pembahasan hasil penelitian yang telah dijabarkan sebelumnya,maka dapat disimpulkan sebagai berikut:

1. Peran pemerintah untuk peningkatan koperasi nelayan dirasakan berpengaruh bagi para anggota koperasi dalam bantuan yang diberikan yang berguna untuk meningkatkan pendapatan ekonomi koperasi nelayan

2. Kebijakan pemerintah tidak berpengaruh secara signifikan akan peningkatan koperasi yang menurut anggota koperasi dalam operasional penangkapan ikannya atau kegiatan koperasi kebijakan pemerintah dirasakan belum menyentuh ke semua koperasi nelayan yang ada di Kota Tanjungpinang

3.Dari kedua variabel bebas yaitu peran dan kebijakan pemerintah dalam upayanya 
membantu peningkatan koperasi nelayan

Kota Tanjungpinang harus berjalan beriring maksudnya adalah jika memang peran pemerintah untuk membantu koperasi nelayan haruslah didasari dengan kebijakan yang memudahkan koperasi perihal pengajuan kebutuhan koperasi tanpa adanya peraturan yang sulit dan persyaratan yang berat secara administratif

\section{SARAN}

1. Peran pemerintah dalam hal membangun perekonomian koperasi nelayan Kota Tanjungpinang harus selalu diwujudkan dengan memberikan bantuan kepada koperasi sesuai dengan kebutuhannya. Bisa diberikan secara tahunan ataupun bantuan yang bersifat penyuluhan sehingga masyarakat nelayan yang menjadi angggota koperasi akan semakin terdidik.

2. Kebijakan yang telah diterapkan dalam hal pemberian bantuan kepada koperasi nelayan haruslah tidak menyulitkan dan aparatur negara harus selalu memberikan sosialisasi kepada koperasi nelayan sehingga bantuan yang telah diberikan dapat dirasakan manfaatnya dan memberi kenyamanan dalam menggunakan tanpa adanya tuntutan hukum apabila salah penggunaan di kemudian hari.

3. Koperasi nelayan harus selalu berkembang dan memperbaiki kelemahan dalam operasionalnya. Bantuan yang diberikan pemerintah dimanfaatkan dengan penuh tanggungjawab demi kesejahteraan para anggota koperasinya.

\section{DAFTAR PUSTAKA}

Anonim. 2009. Laporan Akhir Kajian Implikasi Strategi Koperasi dalam Rangka Otonomi Daerah

Baga, Lukman Mohammad, Rahmat Yanuar, Feryanto W.K, dan Khoirul Aziz. 2009.
Koperasi dan Kelembagaan Agribisnis. Bogor: IPB Press

Dumairy. 1996. Perekonomian Indonesia .

Jakarta:

Ghozali, Imam. 2013. Aplikasi Analisis Multivariate Dengan Program IBM SPSS

21. Semarang: badan Penerbit.

https://industri.kontan.co.id/news/ini-carapemerintah-untuk-sejahterakannelayan-1 (diakses 24 Februari 2019)

Apkapsi. Eksistensi Koperasi di Indonesia. http : www.akapsi.com [25 Februari 2019]. 